\title{
PENGARUH SPONSORSHIP, MEDIA SOSIAL ONLINE, DAN CELEBRITY ENDORSEMENT TERHADAP BRAND AWARENESS PRODUK AKSESORIS GAMING MEREK SADES
}

\author{
Alvin Ginardi \\ Program Studi Magister Manajemen Universitas Tarumanagara \\ alvin_ginardi@hotmail.com \\ Eko Harry Susanto \\ Program Studi Magister Manajemen Universitas Tarumanagara
}

Masuk : 06-12-2020, revisi : 28-12-2020, diterima untuk diterbitkan : 29-12-2020

\begin{abstract}
Online games are no longer considered time-wasting activities. In the past, online games were limited to Personal Computers which had to be connected to an internet cable, but now online games can be accessed anywhere with wireless internet either via a laptop or smartphone. In Gamergear.net's global online game peripherals catalog, there are currently 66 gaming peripherals brands worldwide, one of which is the Sades brand. Sades entered Indonesia through their official distributor PT Indigital Trading in 2011. At first, Sades Indonesia only sold Headset products, and now there are various types of products being sold, namely Headsets, Earphones, Keyboards, Mouse, Mousepad, CPU Case, and CPU Fan. Apart from maintaining the best product quality in its class, Sades Indonesia uses several ways to maintain its Brand Awareness, as 1) Sponsorship for gaming competitions both regional and national, 2) Actively creating content on social media, namely on Instagram, Facebook, and Youtube, 3) Celebrity female gamer, Olivia Gosandra, from 2016 to 2019 as Endorser Sades in Indonesia. This study aims to determine how significant sponsorship, online social media, and celebrity endorsements are for the brand awareness of Sades gaming accessories products in Indonesia. Data obtained from questionnaires distributed via Google Form. The sample used in this study was 80 respondents with the help of SmartPLS version 3.3.2.
\end{abstract}

Keywords: Sponsorship, Online Social Media, Celebrity Endorsement, Brand Awareness

Abstrak: Permainan game online atau dalam bahasa Indonesia nya disebut gim daring tidak lagi dianggap sebagai kegiatan yang membuang waktu. Dahulu gim daring terbatas hanya di Komputer Personal (Personal Computer) yang harus tersambung kabel internet akan tetapi saat ini gim daring dapat diakses dimanapun dengan internet nirkabel baik melalui laptop maupun smartphone. Dalam katalog game peripheral online global Gamergear.net, terdapat 66 merek game peripheral di seluruh dunia saat ini, salah satu nya adalah merek Sades. Sades masuk ke Indonesia melalui distributor resmi mereka PT Indigital Trading di tahun 2011. Sades Indonesia di awal hanya menjual produk Headset, dan saat ini sudah ada bermacammacam jenis produk yang dijual yaitu Headset, Earphone, Keyboard, Mouse, Mousepad, CPU Case, dan CPU Fan. Selain dari menjaga kualitas produk yang terbaik di kelas nya, Sades Indonesia menggunakan beberapa cara untuk menjaga Brand Awareness mereka yaitu: 1) Sponsorship pada kejuaraan gaming baik regional maupun nasional, 2) Aktif membuat konten di social media yaitu di Instagram, Facebook, dan Youtube, 3) Celebrity Gamer Wanita yaitu Olivia Gosandra dari tahun 2016 hingga 2019 sebagai Endorser Sades di Indonesia. Penelitian ini bertujuan untuk mengetahui seberapa signifikan sponsorship, media sosial online dan celebrity endorsement terhadap brand awareness produk aksesoris gaming Sades di Indonesia. Data diperoleh dari kuesioner yang disebar melalui Google Form. Sampel yang digunakan dalam penelitian ini sebanyak 80 responden dengan bantuan SmartPLS versi 3.3.2.

Kata Kunci: Sponsorship, Media Sosial Online, Celebrity Endorsement, Brand Awareness 


\section{PENDAHULUAN}

Pada awalnya hanya 5 perusahaan merek global yang memiliki Brand kuat yaitu Corsair Components (sejak tahun 1994), Logitech (sejak tahun 1981), Mad Catz (sejak tahun 1993), Razer (sejak tahun 2005), SteelSeries (sejak tahun 2001). Akan tetapi seiring dengan bertumbuhnya pemain gim daring secara global, banyak merek-merek baru bermunculan. Dalam katalog game peripheral online global Gamergear.net (2020), terdapat 66 merek game peripheral di seluruh dunia saat ini, salah satu nya adalah merek Sades. Sades, dalam websitenya Sades.gg, berasal dari Shenzhen, China yang memproduksi aksesoris gaming pertamanya yaitu headset di tahun 2002 dan terus berkembang dengan jangkauan penjualan di 54 negara termasuk Indonesia. Target market Sades adalah para gamers dengan budget middleto-low sehingga harga produknya jauh dibawah merek-merek besar global tersebut diatas.

Sades masuk ke Indonesia melalui distributor resmi mereka PT Indigital Trading di tahun 2011. Sades Indonesia (2020) di awal hanya menjual produk Headset, dan saat ini sudah ada bermacam-macam jenis produk yang dijual yaitu Headset, Earphone, Keyboard, Mouse, Mousepad, CPU Case, dan CPU Fan. Saat itu di tahun 2011 Sades Indonesia tidak memiliki kompetitor sebanding, karena hanya ada merek-merek global dengan harga yang cukup tinggi. Akan tetapi saat ini terdapat 50 kompetitor Sades di Indonesia, beberapa yaitu: E-Blue, Rapoo, Rexus, Fantech, Hyper-X, dan lain sebagainya.

Selain dari menjaga kualitas produk yang terbaik di kelas nya, Sades Indonesia menggunakan beberapa cara untuk menjaga Brand Awareness mereka yaitu:

1. Sponsorship pada kejuaran gaming baik regional maupun nasional.

2. Aktif membuat konten di social media yaitu di Instagram, Facebook, dan Youtube.

3. Celebrity Gamer Wanita yaitu Olivia Gosandra dari tahun 2016 hingga 2019 sebagai Endorser Sades di Indonesia.

Dengan begitu banyaknya kompetisi di kelasnya, para kompetitor Sades pasti juga menggunakan strategi yang kurang lebih sama dengan Sades. Akan tetapi Sades tetap unggul di kelasnya. Oleh karena itu saya akan meneliti lebih lanjut dengan menggunakan judul "Pengaruh Sponsorship, Media Sosial Online, dan Celebrity Endorsement terhadap Brand Awareness Produk Aksesoris Gaming Merek Sades di Indonesia"

\section{Tujuan Penelitian}

Tujuan penelitian ini adalah untuk mengkaji sesuai dengan perumusan masalah dalam penelitian yaitu:

1. Untuk mengetahui pengaruh Sponshorship terhadap Brand Awareness Sades di Indonesia

2. Untuk mengetahui pengaruh Media Sosial Online terhaadap Brand Awareness Sades di Indonesia

3. Untuk mengetahui pengaruh Celebrity Endorser terhaadap Brand Awareness Sades di Indonesia.

Berdasarkan uraian diatas maka hipotesis dalam penelitian ini dapat dirumuskan sebagai berikut:

H1 : Sponsorship berpengaruh signifikan pada Brand Awareness Sades Indonesia H2 : Media Sosial Online berpengaruh signifikan pada Brand Awareness Sades Indonesia H3 : Celebrity Endorsement berpengaruh signifikan pada Brand Awareness Sades Indonesia

\section{TINJAUAN PUSTAKA}

\section{Sponsorship}

Shimp (2000) mencoba mendefinisikan sponsorship pada event tertentu sebagai "a form of brand promotion, that ties a brand to a meaningful, athletic, entertaintment, cultural, social, and other type or high interest public activity". Sponsorship adalah sebuah bentuk promosi merek yang menciptakan suatu hubungan antara merek dengan aktivitas yang bermakna dan 
memiliki tingkat minat tinggi di masyarakat seperti acara olahraga, acara musik, acara sosial dan budaya, dan lain sebagainya.

\section{Media Sosial Online}

Menurut Kaplan dan Haenlein (2010), media sosial ialah sebuah kelompok aplikasi berbasis internet yang dibangun di atas dasar ideologi dan teknologi Web 2.0, dan memungkinan penciptaan dan pertukaraan user-generated content. Web 2.0 menjadi platform dasar media sosial. Media sosial ada dalam berbagai bentuk yang berbeda, termasuk social network, forum internet, web blogs, social blogs, micro blogging, wikis, podcasts, gambar, video, rating, dan bookmark sosial.

\section{Celebrity Endorsement}

Selain media promosi yang begitu bervariasi di era digital saat ini, ada hal yang tidak kalah penting yaitu si pembawa pesan pada media promosi tersebut. Sebelum diciptakan nya situs jejaring sosial, media promosi saat itu hanya melalui media TV dan Radio dengan menggunakan model/artis yang cukup dikenal masyarakat. Akan tetapi dengan maraknya situs jejaring sosial online dimana semua orang dapat berlomba-lomba menciptakan konten kreatif mereka dan membuat banyak pengikut online/online followers/subscribers. Dengan banyak pengikut yang mereka miliki dan semakin terkenal mereka, kita menyebut pembuat konten tersebut dengan nama Selebgram/Influencer untuk situs jejaring Instagram dan Youtuber untuk situs jejaring Youtube.

\section{Brand Awareness}

Menurut Lee dan Kotler (2015, p. 561) dengan menciptakan Brand Awareness melalui berbagai media dapat membentuk citra merek dalam ingatan konsumen, dan menimbulkan penilaian atau perasaan terhadap sebuah merek secara positif dan juga dapat memperkuat loyalitas pelanggan.

\section{METODOLOGI PENELITIAN}

Sampel menurut Malhotra (2011) merupakan sebuah sub-kelompok dari unsur-unsur populasi yang telah dipilih untuk berpartisipasi dalam studi penelitian. Sampel dalam penelitian ini adalah konsumen yang memiliki Kesadaran Merek Sades melalui Sponsorship, Media Sosial, dan Celebrity Endorsement yang dilakukan oleh PT Indigital Trading.

Peneliti menyebarkan kuesioner dari tanggal 25 Oktober 2020 hingga 9 November 2020 melalui aplikasi Google Form. Peneliti menyebarkan kuesioner kepada responden dengan 18 pernyataan dan seluruh nya menggunakan metode jawaban skala 1 (sangat tidak setuju) hingga 5 (sangat setuju). Jumlah kuesioner yang diterima sebanyak 80 responden.

\section{HASIL DAN KESIMPULAN}

Berdasarkan hasil pengujian koefisien determinasi diketahui nilai $R$ square adalah sebesar 0,561 yang berarti bahwa sebesar $56.1 \%$ dari dari variabel dependen yaitu brand awareness dijelaskan oleh variabel-variabel yang terdapat dalam penelitian ini dan sisanya yaitu sebesar $43.9 \%$ dijelaskan oleh variabel-variabel diluar penelitian.

Berdasarkan pendapat yang dikemukakan oleh Henseler et al. (2009), maka nilai $R$ square dalam penelitian ini tergolong kuat. Kemudian hasil pengujian dari $\mathrm{Q}^{2}$ dalam penelitian ini adalah sebesar $0,413\left(\mathrm{Q}^{2}>0\right)$ yang berarti bahwa konstruk variabel yang terdapat dalam penelitian ini relevan untuk mengukur model penelitian yang telah terbentuk sebelumnya dengan baik (Hair et al. 2011). Akan tetapi hasil pengujian Hipotesis menunjukan bahwa hanya H1 saja yang lolos uji. Hasil pengujian disajikan pada tabel di bawah ini. 
Tabel 1

Hasil Uji Bootrstraping

\begin{tabular}{|c|c|c|c|}
\hline & Path Coefficients & T Statistics & P Values \\
\hline Sponsorship -> Brand Awareness & 0.461 & 2,594 & 0,011 \\
\hline Media Sosial Online -> Brand Awareness & 0.207 & 0,830 & 0,409 \\
\hline Celebrity Endorsement -> Brand Awareness & 0.130 & 0,910 & 0,365 \\
\hline
\end{tabular}

Berdasarkan hasil pada Tabel 1, variabel Sponsorship terbukti mampu memberikan pengaruh secara signifikan pada brand awareness atau kesadaran merek terhadap aksesoris gaming merek Sades. Hal ini dibuktikan dengan nilai $t$ statistics sebesar 2,594 yang lebih besar dari cut off value sebesar 1,96 dan p-values nya yaitu 0,011 lebih kecil dari cut off value yang ditetapkan yaitu sebesar 0,05 sehingga dapat disimpulkan bahwa $\mathrm{H}_{1}$ tidak ditolak.

Sedangkan, variabel Media Sosial Online ternyata tidak memberikan pengaruh signifikan pada brand awareness aksesoris Gaming Merek Sades. Hal ini dibuktikan dengan nilai $t$ statistics sebesar 0,830 yang lebih kecil dari cut off value sebesar 1,96 dan p-values nya yaitu 0,409 lebih besar dari cut off value yang ditetapkan yaitu sebesar 0,05 sehingga dapat disimpulkan bahwa $\mathrm{H}_{2}$ ditolak. Kemudian juga variabel Celebrity Endorsement ternyata memberikan pengaruh negative pada brand awareness aksesoris Gaming Merek Sades. Hal ini dibuktikan dengan nilai $t$ statistics sebesar 0,910 yang lebih kecil dari cut off value sebesar 1,96 dan $p$-values nya yaitu 0,365 yang lebih besar dari cut off value yang ditetapkan yaitu sebesar 0,05 sehingga dapat disimpulkan bahwa $\mathrm{H}_{3}$ ditolak.

Analisa peneliti terhadap variabel Media Sosial Online Sades Indonesia tidak bepengaruh signifikan terhadap brand awareness adalah faktor iklan/ads tidak digunakan oleh Sades di social media Youtube, Instagram, dan Facebook sehingga apabila kita melihat jumlah view/penonton di kanal Youtube Sades Indonesia tidak banyak, terbanyak adalah 41,000 penonton pada video 3 tahun lalu dan terendah adalah 135 penonton video terbaru. Kemudian Instagram hanya 30,100 pengikut dan berbanding jauh dengan jumlah likes yang ada di postingan Instagram Sades Indonesia. Selanjutnya terhadap variabel Celebrity Endorsement Sades Indonesia tidak berpengaruh signifikan terhadap brand awareness adalah faktor figure si selebriti yang dipilih oleh Sades Indonesia bukan top 10 gamer populer di Indonesia menurut website duniagames.com besutan Telkom Indonesia (Syahdan, 2019). Sehingga kurang berperngaruh signifikan terhadap brand awareness produk gaming merek Sades. Kemudian alasan sponsorship memberikan pengaruh signifikan terhadap brand awareness produk gaming Sades Indonesia karena memang menurut GM PT Indigital Trading adalah bahwa Sades selalu berpartisipasi dalam acara gaming di Indonesia sehingga merupakan hal wajar masyarakat mengetahui produk gaming merek Sades tersebut.

\section{DAFTAR PUSTAKA}

GamerGear. (2020). Gaming brands, products and specifications. Gamergear.Net. https://www.gamergear.net/brands.php

Henseler, J., Ringle, C. M., \& Sinkovics, R. R. (2009). The use of partial least squares path modeling in international marketing. Advances in International Marketing, 20, 277-319. https://doi.org/10.1108/S1474-7979(2009)0000020014

Kaplan, A. M., \& Haenlein, M. (2010). Users of the world, unite! The challenges and opportunities of Social Media. Business Horizons, 53(1), 59-68.

https://doi.org/10.1016/j.bushor.2009.09.003

Lee, N. R., \& Kotler, P. (2015). Social marketing: Changing behaviors for good. Sage Publications.

Malhotra, N. K. (2011). Review of marketing research: Special issue-Marketing legends. Emerald Group Publishing Limited. https://doi.org/10.1108/s15486435(2011)0000008015

Sades. (2020). Company Sades. Sades.Gg. https://www.sades.gg/about_SADES/ 
Shimp, T. A. (2000). Periklanan promosi: Aspek tambahan komunikasi pemasaran terpadu (5th ed.). Erlangga.

Syahdan. (2019). Inilah 10 Youtuber gaming Indonesia dengan subscriber terbanyak di tahun 2019. Duniagames.Co.Id. https://duniagames.co.id/discover/article/inilah-10-youtubergaming-indonesia-dengan-subscriber-terbanyak-2019 